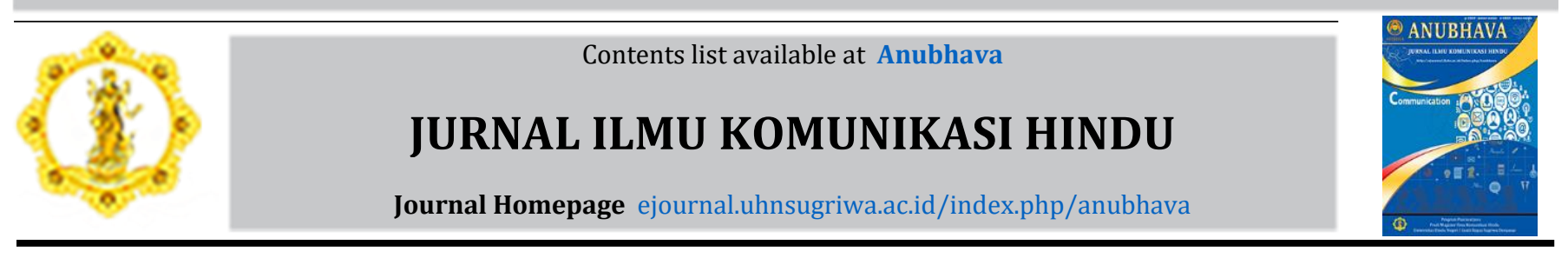

\title{
JARGON POLITIK AGAMA DAN BUDAYA PASANGAN CALON KOSTER-ACE SEBAGAI MEDIA KOMUNIKASI POLITIK DALAM PEMILIHAN GUBERNUR BALI 2018
}

\author{
Dewa Putu Agus Sanjaya Putraa ${ }^{\mathrm{a}, 1}$ \\ I Nyoman Yoga Segara ${ }^{a}$ \\ I Gede Sutarya ${ }^{a}$
}

\author{
a Universitas Hindu Negeri I Gusti Bagus Sugriwa Denpasar \\ ${ }^{1}$ Corresponding Author, email dewasanjaya@gmail.com (Putra)
}

\section{ARTICLE INFO}

\section{Article history:}

Received: 27-01-2021

Revised: 19-02-2021

Accepted: 09-03-2021

Published: 31-03-2021

Keywords:

Political jargon,

religion and culture,

political

communication
ABSTRACT

Since the year 1999, the election method applied in Indonesia was representative election. A great change occurred when Law number 32 year 2004 was legalized. As a result, politics in Indonesia also changed. The head of a region is directly elected by all people. During Balinese governor election in 2018, politic communicators start to focus the style of their politic communication by using cultural and religious political jargons to gain Balinese sympathy. Based on the illustration above, this research focuses on discussing about (1) the constructive material of political jargons which uses religion and culture as political communications during Balinese governor election 2018, (2) electors' perception towards the use of religion and culture as political jargons during Balinese governor election 2018, (3) political communication models using religion and culture during Balinese governor election 2018. The theories applied in analyzing research problems are dramaturgy theory by Erving Goffman. This research employs qualitative method. By applying qualitative method, the data being analyzed is descriptive data in the form of written and verbal words and observable behavior performed by politicians. The study reveals the following results. First, the material of religious and cultural political jargons used by the candidates of Balinese governor are the use of Balinese alphabets, color symbols, and traditional clothes which are used as a tool in political dramaturgy during the campaign. Second, the electors' perceptions on the use of political jargons as communicative media during Balinese governor elections is a positive thing. The result of the survey shows that the electors are interested in electing the candidate because of the religion and cultural jargons as political communicative media. Third, there are positive and negative outputs for the political communication model.

\section{PENDAHULUAN}

Pemilihan kepala daerah (Pilkada) terus mengalami perubahan. Bahkan dari tahun 1999, penggung demokrasi di Indonesia telah mengalami perubahan. Pemilihan kepala daerah sempat dilakukan dengan sistem perwakilan yakni Gubernur dan Wakil Gubernur, Bupati dan Wakil Bupati, serta Walikota dan Wakil Walikota dipilih oleh anggota Dewan Perwakilan Rakyat Daerah (DPRD). Kemudian di tahun 2014 
perubahan kembali terjadi yakni menggunakan pola pemilihan kepala daerah yang dipilih secara langsung oleh masyarakat yang sudah memiliki hak pilih dalam.

Berdasarkan dari dinamika aturan tersebut, komunikasi politik aktor Pilkada juga ikut berubah. Mereka ereka tidak hanya meraih simpati para anggota DPRD, tapi kepada seluruh masyarakat didaerah pemilihannya. Hal ini juga tak terlepas di wilayah Bali yakni Pemilihan Gubernur (Pilgub) Bali 2018, fokus komunikator politik pun berubah untuk mendapat simpati masyarakat Bali. Pertarungan Politik dalam Pilgub Bali tidak saja bertarung antara figure calon dengan idiologi partai politik pengusung, tapi juga pertarungan dalam menunjukan idiologi para calon sebagai masyarakat Bali yang perduli dengan Bali. Hal yang cukup menjadi kontra diktif adalah meskipun Undang-Undang Pilkada tersebut telah mengatur terkait politik identitas atau pengaturan propaganda terhadap suku, agama, ras dan antargolongan (SARA) sesuai dengan pasal 69 huruf $b$, namun faktafakta dilapangan penggunaan politik identitas ini masih terjadi dalam Pilkada dan ini juga terjadi dalam Pilgub Bali 2018. Tapi jika dicermati pasal 69 tersebut disana hanya mengatur bahwa dalam masa kampanye dilarang menghina seseorang, ataupun SARA. Kata menghina SARA tersebut jika dipersepsikan sangat luas sementara Undang-Undang Pilkada tidak mendetailkan kata menghina tersebut.

Untuk menunjukkan kedua pasang calon (Paslon) Pilgub Bali ini sangat peduli dengan nasib Bali kedepan, mereka Dr. Ir. I Wayan Koster - Dr. Tjokorda Oka Artha Ardana Sukawati (Koster-Ace) dan Paslon, Ida Bagus Rai Wijaya Mantra-Ketut Sudikerta (Mantra-Kerta) tersebut mengeluarkan sejumlah visi misi yang melindungi Bali serta jargon-jargon politik yang berbasis agam dan budaya dalam komunikasi politik mereka, seperti visi misi Koster-Ace yakni, Nangun Sat Kerthi Loka Bali sementara pasangan Mantra-Kerta menggunakan visi misi Nawa Candra.
Sementara diperhelatan Pilgub Bali tahun 2018 tersebut, masyarakat Bali cendurungan lebih memilih pasangan nomor urut 1 yakni Koster-Ace dengan jargon politik Nangun Sat Kerthi Loka Bali sebagai visi dan misinya, jargon tersebut lebih memberikn filosofi mendalam pada konsep agama Hindu dan menjadi bagian propaganda politik mereka. Konsep anasir agama dan budaya ini pun mejadi media dalam komunikasi politik memenangkan Pilgub Bali tahun 2018. Selain itu, faktor lain juga mendukung kemenagan calon yang diusung empat parpol ini diantaranya kesolidan partai dalam memangakan pasangan tersebut serta isu pemerataan pembangunan diseluruh Bali melalui penjabaran visi-misi Nangun Sat Kerthi Loka Bali. Dari data KPU Bali pada Pilgub 2018 lalu, Paslon Koster-Ace unggul sebesar 1.213.075 suara dibandingkat Pasangan Ida Bagus Dharmawijaya Mantra yang hanya memperoleh 889.930 suara. Untuk lebih jelas lihat table 1 kemenganan Koster-Ace di setiap Kabupaten di Bali, (sumber hasil rekapitulasi KPU Bali tahun 2018).

Mengingat keterbatasan waktu penelitian, penelitian ini fokus pada satu calon saja yakni Koster-Ace dengan jargon politik anasir agama dan budaya untuk mendompleng kemenangannya di Pilgub Bali tahun 2018 lalu. Peristiwa ini pun cukup menarik untuk diteliti mengingat, para calon kepala daerah dalam komunikasi politik tidak hanya menjadi komunikator infrastuktur dan janji kepentingan politik semata. Namun, komunikasi politik yang disajikan dalam jargon yang menggunakan anasir agama dan budaya pada Pilgub Bali 2018 ini para calon kepala daerah juga berperan sebagai dharma pracaraka dalam mendesiminasikan konsep ajaran Hindu seperti jiwa Ksatriya Varna. Kewajiban Ksatriya Varna menurut Bhagawad Gita XVIII.43 yakni Saurya: pemberani memiliki sifat kepahlawanan, Teja: perkasa berwibawa, Drhti: tabah hati dan teguh hati, Yuddheca'palaayanam: tidak pernah mundur dalam pertarungan, Daanam: 
dermawan dan Isabhawa: memiliki bakat pemimpin. Selain itu, penelitian ini penting dilakukan karena hasil kajian ini akan mampu memberikan rekomendasi dan refrensi yang inovatif kepada seluruh sipil (civil society) baik masyarakat pemilih, partai politik, konsultan politik, lembaga riset, tim sukses, lembaga Public Relations maupun aktor politik saat bertarung dalam Pemilu.

Dalam konteks penelitian ini, penulis melakukan penelitian pada Pemilihan Gubernur Bali, karena pemilihan kepala daerah serentak dilaksankan tanggal 27 Juni 2018 dan Pilkada Provinsi Bali masuk didalamnya. Para calon dalam Pilgub tersebut menggunakan jargon anasir agama dan budaya dalam penyamapain visi dan misi mereka baik dalam propaganda maupun kegiatan kampanye di sejumlah wilayah di Bali. Tak hanya itu, penulis tertarik melakukan penelitian ini adalah masih minimnya literatur yang membahas mengenai komunikasi politik yang berkasanah konsep hindu, kebanyakan literatur yang penulis temukan adalah membahas komunikasi politik secara umum.

\section{Rumusan Masalah}

Sesuai paparan tersebut peneliti dapat merumuskan masalah dalam artikel ini yakni ;

1. Bagaimana materi konstruksi jargon politik dengan mengunakan agama dan budaya sebagai komunikasi politik dalam Pilgub 2018 ?

2. .Bagaimana persepsi pemilih terhadap penggunaan agama dan budaya sebagai jargon politik dalam Pilgub Bali 2018 ?

3. Bagaimana model komunikasi politik dengan menggunakan agama dan budaya dalam Pilgub Bali 2018?

Penelitian memiliki tujuan untuk mengetahui bentuk komunikasi politik yang dikembangkan dan dikemas dalam jargon politik berbasis agama dan budaya sebagai media komunikasi politik dalam Pilgub Bali 2018.

\section{Jargon Politik}

Sebagai komunikator politik banyak sekali jargo-jargon dilontarkan oleh para elit politik apa sebenarnya kata Jaron tersebut. Dari penelususran penulis melalui Kamus Besar Bahasa Indonesia versi dalam jaringan (online), kata jargon berarati kosakata khusus yang digunakan dalam bidang kehidupan tertentu.

Sementara Sufyanto (2015:5) mengatakan jargon merupakan suatu idiom-idiom yang dipergunakan sejumlah komunikator baik komunikator politik untuk mengasumsikan sesuatu baik itu ideologi, memonopoli identitas. Hal ini sering dilihat dalam perhelatan pemilihan umum maupun pemilihan kepala daerah termasuk di Pilgub Bali 2018. Jargon berbasis agama -budaya sangat kental digunakan terutama dalam menyampiakan pesan visi misi calon kandidat.

Jargon Politik dapat disimpulkan suatu idiom-idiom atau gabungan kata yang bermakna khusus untuk bisa memonopoli identitas dalam agenda-agenda politik. Jargon politik ini biasanya digunakan oleh para calon kepala daerah baik yang petahana maupun nonpetahana. Biasanya bagi calon petahana menggunakan jargon politik berupa bahasa atau kalimat "Melanjutkan Pembangunan" sedangkan non-petahana biasanya menggunakan Bahasa yang bermakna "perubahan" atau kalimat "Kearah yang Lebih Baik". Tapi, dalam hal ini yang mejadi benang merah penelitian ini adalah jargon politik yang menggunakan anasir agama dan budaya baik berupa Bahasa, pakaian dan iklan.

\section{Anasir Agama dan Budaya}

Perhelatan politik lokal, pencitraan berbasis dimensi agama dan budaya untuk menarik simpati masyarakat masihlah sangat diminati oleh para aktor politik. Dalam Pilgub Bali 2018 calon kadidat sangat kental menggunakan anasir agama dan budaya Bali. Menurut Greet Hofstede yang disadur oleh Lustig \& Koester $(2010 ; 113)$, manusia membawa suatu program di dalam 
benaknya yang berperan sebagai software of the mind. Program mental ini memuat berbagai ide mengenai suatu budaya dan diekspresikan melalui nilai-nilai dominan.

Di Bali, budaya sangat identik dengan agama dan agama hindu di Bali juga merupakan anasir kebudayaan Bali itu sendiri. Dari pendapat Hofstede, penulis menyumpulkan bahwa anasir agama dan budaya dalam Pilgub Bali ini adalah sebuah komunikasi politik indentitas dengan penggunaan konteks agama Hindu Bali dan Budaya Bali.

\section{Komunikasi Politik}

Pengertian komunikasi politik ada sejumlah literarur yang ditemukan diantaranya dari Kamus Besar Bahasa Indonesia (KBBI). Komunikasi adalah pengiriman dan penerimaan pesan terhadap dua orang atau lebih dan maksud pesan tersebut dapat dipahami (Departemen Pendidikan Nasional,2015:721). Selain itu pakar Komunikasi Hafied Cangara menjabarkan, komunikasi politik adalah suatu proses komunikasi yang memiliki implikasi atau konsekuensi terhadap aktifitas politik. Komunikasi politik memiliki pesan yang bermualan politik (Cangara, 2016;30).

Sementara B. Aly (2010:63) menyatakan, komunikasi politik merupakan suatu kegiatan penyampaian pesan politik yakni aktor politik atua Kamunikan Politik kepada masyarakat atua pemilihnya secara timbal balik. Respon Kounikan politik yang diharapkan yang diharapkan seperti terjadinya pengambilan keputusan politik secara demokratis, transparan.

Dari definisi sejumlah ahli tersebut penulis menyimpulkan Komunikasi Politik adalah salah satu aktivitas komunikasi yang tujuannya untuk mengirimkan pesan politik dan dapat diterima mapun ada timbal balik dari masyarakat atau pemberi suara (vote).

\section{Teori Dramaturgi Erving Goffman}

Sebutan Dramaturgi dalam benak dan pikiran pasti tertuju pada kegiatan drama maupun teater diatas panggung. Dimana para aktor sedang melakukan seni pertunjukan dengan memainkan berbagai karakter seseorang. Konspe Teori Dramaturgi Erving Goffman terdiri dari Front stage (panggung depan) dan Back Stage (panggung belakang). (sufyanto,2015:52)

Front Stage (panggung depan) yaitu konsep ini dalam pertunjukan memiliki fungsi mendefinisikan situasi pemndagan fisik. Front stage ada dua bagian yakni;. Pertama, penggambaran suasana yang mesti dilakukan sang aktor memainkan perannya, Dan kedua Front Personal yaitu berbagai macam perlengkapan sebagai pembahasa perasaan dari sang aktor. Menurut Goffman (1974) , "first tere is 'setting', involving furniture, décor, pshical layout, and other background items which supplay the scenery and stage props for the spate of human action played out before, within or upon it". (Goffman,1974:32-33)

Back stage (panggung belakang) yaitu ruang dimana disitulah berjalan skenario pertunjukan oleh "tim" (masyarakat rahasia yang mengatur pementasan masing-masing aktor). Goffman mendalami dramaturgi dari segi sosiologi. Ia menggali segala macam perilaku interaksi yang dilakukan dalam pertunjukan kehidupan kita sehari-hari yang menampilkan diri kita sendiri dalam cara yang sama dengan cara seorang aktor menampilkan karakter orang lain dalam sebuah pertunjukan drama. Cara yang sama ini berarti mengacu kepada kesamaan yang berarti ada pertunjukan yang ditampilkan.( Goffman,1974:50-51)

Landasan teori ini cukup mampu menjelaskan fenomena jargon berbasis agama dan budaya sebagai media komunikasi politik dalam Pilgub Bali 2018 dimana dalam menegosiasikan keinginan dan tujuan politisi dengan konstituen pemilihnya menggunakan material jargon politik berupa iklan politik dan 
kandidat kontestan politik harus mampu membawa dirinya pada situasi sosial, sekalipun meraka harus menyembunyikan performa diri yang sesungguhnya dan mengganti identitas diri sebagi politisi

\section{METODE PENELITIAN}

Sasaran subjek dalam penelitian ini adalah Paslon Koster-Ace yang mengikuti Pilkada serentak 2018. objek penelitian adalah jargon berbasis agama dan budaya sebagai modal komunikasi politik calon Gubernur dan Wakil Gubernur pada pemilihan kepala daerah langsung atau Pilgub Bali tahun 2018. Di penelitian ini akan mengambil satu pasang calon saja yang telah berhasil memenagkan Pilgub Bali. Hal ini dilakukan untuk membatasi penelitian agar tidak terlalu meluas.

Jenis penelitian tesis ini menggunakan pendekatan kualitatif karena bersifat realitas, pendekatan kualitatif mengandung persepsi subjektif bahwa realitas (komunikasi) bersifat ganda, rumit, semu, dinamis (mudah berubah), dikontruksikan, dan holistik; kebenaran realitas bersifat relatif (Mulyana, 2001:147). Dalam penelitian ini, pendekatan kasus yang diamati yakni Jargon berbasis Agama dan Budaya Pasangan Calon Koster-Ace sebagai media Komunikasi Politik Pilgub Bali tahun 2018. Peneliti berusaha mengamati, memahami, dan menganalisis jargon anasir agama dan budaya yang dijadikan Komunikasi Politik calon Gubernur dan Wakil Gubnernur pada Pilgub Bali tahun 2018.

\section{HASIL DAN PEMBAHASAN \\ Rekomendasi Koster-Ace dalam Pilgub Bali 2018}

Sabtu 11 November 2017 merupakan hari bersejarah bagi pasangan calon Gubernur Bali dan wakil Gubernur Bali, I Wayan Koster dengan Tjokorda Oka Artha Ardana Sukawati (KosterAce). Dihari tersebut, merupakan turunnya rekomendasi pasangan itu untuk bertarung dalam Pilgub Bali 2018 dari Dewan Pimpinan
Pusat (DPP) PDI Perjuangan. Bahkan saat itu Ketua Umum DPP PDI Perjuangan, Megawati Sukarno Putri didampingi Sekjen DPP PDI Perjuangan, Hasto Kristianto memberikan secara langsung rekomendasi tersebut di Kantor DPP PDI Perjuangan di Jakarta.

Ketua Umum Partai Demokrasi Indonesia Perjuangan (PDIP) Megawati Soekarnoputri juga sempat memberikan alasan mengapa ia memberikan rekomendasi tersebut kepada kedua pasangan itu pada Pemilihan Gubernur Bali 2018. Menurut Megawati saat itu, salah satu alasannya adalah latar belakang Koster yang pernah menjadi anggota dewan selama tiga periode. Dengan latar belakang anggota dewan, maka seorang calon pemimpin daerah juga telah mengerti aturan perundangan-undangan dan tata kelola pemerintahan.

Ketua BSPN PDI Perjuangan Propinsi Bali, I Ketut Suiasa mengatakan, Wayan Koster kala itu sebelum menjadi calon Gubernur Bali menjabat sebagai anggota Komisi X DPR RI. Wayan Koster lahir di Singaraja tanggal 20 Oktober 1962. Dia memulai pendidikan dasar di Bali sebelum akhirnya melanjutkan perguruan tinggi di Institut Teknologi Bandung (ITB). Selepas menamatkan jenjang universitas, ia kemudian melanjutkan kiprah di dunia pendidikan. Tercatat, ia pernah menjadi peneliti Badan Penelitian dan Pengembangan (Balitbang) Departemen Pendidikan dan Kebudayaan antara tahun 1988 hingga 1944.

Sementara calon wakil Gubernur Bali, Tjokorda Oka Arta Ardana Sukawati, kiprahnya dalam dunia birokrasi juga sangat dikenal. Pria yang akrab disapa Cok Ace ini pernah menjadi Bupati Gianyar selama dua periode yakni 20032008 dan 2008-2013. Tokoh Puri Ubud, Kabupaten Gianyar ini juga merupakan akadeisi ternama di Bali. Cok Ace menempuh S1 jurusan Arsitektur dan S2 jurusan Kajian Budaya di Universitas Udayana. Dia juga mengambil program S3 dan lulus menjadi Doktor Kajian Budaya di universitas yang sama dan kini ia telah 
memperoleh status guru besar di Institus Seni Indonesia Denpasar. Cok Ace juga salah satu dosen di universitas tersebut. Selain bidang pemerintahan dan akademik, Cok Ace juga pelakon seni dan praktisi pariwisata. Dia terpilih sebagai Ketua Persatuan Hotel dan Restoran Indonesia (PHRI) Bali selama dua periode. Ia juga pada April 2017 silam sempat menjabat sebagai Konsul Kehormatan Malaysia untuk Bali.

\section{Konstruksi Meteri Jargon Politik Agama dan Budaya dalam Pilgub Bali 2018}

Jargon politik sering sekali berkaitan dengan budaya politik citra dalam panggung pemilihan kepala daerah maupun pemilihan umum yang datang tiap lima tahun sekali. Bahkan jargon politik dijadikan bagian dalam iklan politik yang sudah menjadi agenda penting dalam rangkaian kegiatan politik. Disadari maupun tidak jargon politik ini memudahlan calon dalam menjabarkan visi dan misi mereka para calon kepala daerah yang sedang bertarung dalam perhelatan demokrasi baik di pusat maupun di daerah.

Untuk di pemilihan kepala daerah di Provinsi Bali jargon politik agama dan budaya sebagai media komunikasi politik sangat kental terlihat dalam iklan kampnaye mereka. Peneliti menemukan sejumlah iklan politik calon kepala daerah untuk media cetak (spanduk yang dipasang oleh KPU Privinsi Bali) kususnya pasangan Nomor urut 1, Dr. Ir. I Wayan Koster, MM (Cagub) dan Dr. Ir. Tjokorda Oka Artha Ardana Sukawati, M.Si (Cawagub) termuat sejumlah konten dan tulisan yang kental dengan agama dan budaya.

Latar belakang merah dengan degradasi putih serta latar belakang foto bendera merah putih dalam iklan berupa spanduk yang dipasang KPU Bali dapat dikonotasikan semangat nasionalis. Pesan latar belakang iklan tersbeut secara tak langsung meberikan penanda dalam pikiran bawah sadar, bahak pangangan tersebut memiliki idiologi nasionalis yang tinggi. Pesan ini pun juga sempat menjadi bahasan Roland
Berthes (1957), pakar semiotoka tentang perikilnan yakni sebuah iklan centak tentang gaya hidup yakni sebuha iklan merek anggur berkarbonasi Marilyn Peace yang ditemukan dibanyak majalah eropa beberapa tahun lalu. Tujuan utama dari sebagian besar periklanan kontemporer adalah mengajak secara tak langsung ikut berpikir dalam alam bawah sadar yang meihat iklan tersebut, (Danies :2011;305). Selain latar belakang mencerminkan nasionalis, ada penanda lain yang memperkuat jadi diri paslon Koster Ace seolah-olah memberikan pesan jargon agam dan budaya masuk dalam iklan tersebut yakni warna tulisan huruf dan angka dominan merah, putih hitam ini juga sebagai simbol budaya dan agama Hindu masyarakat Bali. Warna merah, putih dan hitam ini sebagai simbol tridatu yakni tiga elemen dalam konsep agama Hindu di Bali.

Tak hanya bagian iklan cetak, busana yang digunakan Pasangan calon Koster-Ace juga menjadi salah satu jargon Agama dan Budaya yang dilakukan saat kampanye Pilgub Bali 2018. Selama kampanye maupaun menghadiri kegiatan resmi dan non resmi di Bali kedua pasangan ini menggunakan busana adat Bali. Bahkan didalam foto yang dipakai sebagai surat suara juga menggunakan busana adat Bali dengan busana adat madya.

Calon Gubernur Bali, Wayan Koster mengenakan pakaian putih dan mengenakan udeng jejateran atau babidakan. Sementara Calon Wakil Gubernur Tjok. Oka Artha Ardana Sukawati menngunakan pakaian hitam dan udeng dara kepek. Dalam konsep tradisi budaya Bali ada beberapa jenis udeng, diantaranya udeng atau destar jejateran, dara kepek dan destar bablatungan., Namun dalam pembahasan konsep jargon agama dan budaya dalam berpakaian adat Koster-Ace peneliti hanya membahas dua udeng saja yang digunakan dalam busana pencitraan yang digunakan kedua pasanang tersebut.

Dari sisi konsep penggunaan udeng Calon Gubernur Bali Wayan Koster, bahwa udeng 
jejateran itu merupakan simbul dalam umat Hindu Bali sebagai pengikat manah (memusatkan pikiran) dan bisanya udeng ini digunakan untuk kegiatan persembahyangan. AA Ayu Ketut Agung mengatakan, simbul udeng jejteran ini adalah mencari peningkatan hidup spiritual dan bisanya sering digunakan pada saat ke pura atau persembahyangan (Ketut Agung; 2018;56).

Sementara konsep udeng dara kepek yang digunakan Calon Wakil Gubernur Tjok. Oka Artha Ardana Sukawati menyimbolkan warna kestria. Udeng ini memberikan konsep seorang pemimpin yang senantiasa mengayomi rakyatnya. Udeng ini bisangan dipakai oleh para tokoh-tokoh puri di bali yeng mengisyaratkan budaya busada seorang tokoh puri sekaligus seorang budayawan. Pakar Busana Adat Bali, AA Ayu Ketut Agung juga menyebutkan, penggunaan udeng-udeng dara kepek ini bisanya digunakan oleh orang-orang yang memiliki kedudukan dan status sosial tertentu seperti budayawan, upareka, kelihan dan sering memiliki pikiran dinamis. (Ketut Agung;2018;57)

Selain itu, dalam pengunaan busana adat Bali berupa udeng, Tjok. Oka Artha Ardana Sukawati juga menggunakan bunga pucuk rejuna di udeng. Selain sebagi simbul budaya masyarakat Bali, pucuk ini juga sebagai perlambang maskot Kabupaten kelahiran Cok Ace di Gianyar. Bunga pucuk rejuna juga dilambangkan kewibawaan dan kangungan dalam berbusana.

Konsep Agama dan budaya dalam berpakaian adat ini tidak saja masuk hanya pada saat melakukan kampanye di Pilgub Bali, namun setelah mereka lolos menjadi Gubernur dan Wakil Gubernur Bali, Koster-Ace melanjutkan penggunaan busana adat Bali dalam bentuk pembuatan Peraturan Gubernur Nomor 79 tahun 2018 tentang Hari Penggunaan Busana Adat Bali yang telah ditetapkan pada 26 September 2018. Sesuai dengan Pergub tersebut ada sejumlah tujuan yang dituangkan dalam hari penggunaan busana adat Bali diantaranya pertama dalaha menjaga dan memilihara kelestraian busana adat Bali dalam rangka meneguhkan jati diri, karakter, dan budi pekerti. Kedua adalah menyelaraskan fungsi busana adat Bali dalam kehidupan masyarakat sejalan dengan arahan pemajuan kebudayaan Bali dan Indonesia. Ketiga adalah mengenali nilai-nilai estetika, etika, moral dan spiritual yang terkandung dalam budaya Bali untuk digunakan sebagai upaya pembinaan dan pengembangan kebudayaan Nasional. Tujuan keempat, adalah mendorong peningkatan pemanfaatan produk dan industry busana lokal Bali. Sementara waktu dan tempat penggunaan dilakukan setiap hari Kamis,Purnama, Tilem, dan Hari Jadi Provinsi Bali pada tanggal 14 Agustus.

\section{Persepsi Pemilih terhadap Penggunaan Agama dan Budaya sebagai Jargon Politik}

Menurut Ketut Suiasa, persepsi di masyarakat dalam penggunaan komunikasi politik dengan konten agama dan budaya masih relevan di digunakan di Bali, karena kultur pemilih di Bali sangat khas dengan adanya kedekatan agama budaya. "Kebetulan calon kami bisa melakukan kombinasi dalam mengangkat nilai kearifan lokal yang dimiliki Bali sebagai jargon, yakni budaya dan agama. Meski terlihat menyatu, namun konsepnya untuk menarik masyarakat dalam ikut dalam gerakan melakukan hak politinya dalam hal ini ikut memilih saat Pilkada lalu bukanlah hal yang salah. Dan saya yakin masyarakat mengenatui komunikasi politik yang kita lakukan mengarah kemana dan bukan ke unsur pelanggaran atau SARA" (wawancara, Suiasa, 2 Oktober 2019)

Untuk menguatkan pernyataan Ketut Suiasa dan mengenatui persepsi pemilih terhadap penggunaan agama dan budaya sebagai jargon politik, peneliti melakukan survei terharap 100 responden secara acak di kawasan perkotaan dan pedesaan, dengan menyebarkan kuesioner ke delapan kabupaten dan satu kota se-Bali. Kegiatn survey yang peneliti lakukan bukan sebagai alat untuk melakukan analisis, namun 
sebagai display data untuk menguatkan apa yang dikatakan oleh narasumber kunci peneliti. Karena, penelitian ini bersifat kualitatif. Meminjam pemikirannya Philip Kotler dalam bukunya Marketing 4.0, Jargon Politik Agam dan Budaya peneliti ibaratkan sebagai brand atau merek maupun produk. Kotler membuat konsep lima A dalam pemetaan pelanggan untuk melakukan survei brand atau produk yakni Aware (menyadari ada iklan jargon agama budaya tersebut), Appeal (Tertarik dengan iklan jargon agama budaya), ask (bertanya), act (bertindak) dan advocate (menganjurkan) (Kotler, 2019: 59).

Menurut Kotler, kerangka lima A adalah alat fleksibel yang bisa diterapkan pada semua industri. Bila digunakan untuk menggambarkan perilaku pelanggan bahkan persepsi masyarakat terhadap suatu produk alat ini membuat gambar yang mendekati dengan jalur pelanggan yang sebenarnya (Kotler, 2019:63). Disini peneliti pun menggunakan kerangka lima A tersebut dalam melakukan survei persepsi peilih dalam Pilgub Bali terhadap iklan jargon agama budaya KosterAce yang sempat dijadikan media komunikasi politik dalam kampanye Pilgub Bali 2018 lalu.

Dari pemetaan Lima A tersebut ada lima pengukuran yang dilakukan terhadap jargon politik agama budaya dalam persepsi masyarakat atau pemilih saat Pilgub Bali. Pertama adalah aware. Sejauhmana masyarakat tahun akan keberadaan jargon politik agama budaya tersebut. Kedua adalah appeal. Hal ini mengukur apakah masyarakat tertarik dengan iklan jargon agama budaya tersebut. Ketiga adalah Ask, elemen ketiga ini adalah untuk mengukur persentase masyarakat yang disurvei keingintahuan mereka terhadap jargon politik agama budaya ini. Kepempat adalah Act, yakni untuk mengukur sejauhmana masyarakat melakukan tindakan untuk memilih calon dari jargon agama budaya tersebut. Kelima adalah advocate. Hal ini mengukur sejauh mana masyarakat yang telah memilih akibat melihat jargon agama budaya Koster-Ace ikut untuk menganjurkan orang lain untuk ikut memilih calon tersebut dalama Pilgub Bali.

Hasil survei masyarakat dalam tahap menyadari adanya jargon politik agama budaya sebagai media komunikasi politik dalam Pemililihan Gubernur Bali 2018 yakni ; 92.8 persen menyadari adanya iklan jargon politik agama budaya tersebut digunakan sebagai media komunikasi politik dalam Pimilihan Gubernur 2018 dan 8,2 persen belum atau tidak benyadari hal itu. Hasil survei ketertarikan masyarakat dengan adanya jargon politik agama budaya dalam Pemilihan Gubernur 2018 menunjukan hal positif, yakni dengna hasil 78,1 persen mengaku tertarik dengan penggunaan jargon politik agam dan budaya tersebut dan 21,9 persen tidak tertatik dengan sajian jargon politi agama budaya sebagai media komunikasi politik dalm Pemilihan Gubernur 2018. Hasil survei masyarakat ingin mencari tahu penggunaan jargon agama budaya sebagai media komunikasi politik dalam Pilgub Bali sepertinya cukup besar yakni 78, 4 persen dan masyarakat yang tak ingin mencari tahun sebesar 21,6 persen. Hasil survey masyarakat seteah mencari tahu serta melihat jargon agama budaya dalam Pemilihan Gubernur Bali 2018, partisiapsi memilih masyarakat meningkat. Masyarakat yang disurvei mengaku tertarik memilih dalam Pemilihan Gubenrnur Bali salah satunya adanya jargon agama budaya. Ada sebanyak 87,6 persen mengaku tertarik untuk memilih dalam Pilgub Bali utamanya calon nomor 1 Paslon Koster-Ace dan 12,4 persen tidak tertarik memilih. Bahkan Tim pemenagan Koster-Ace, Ketut Suiasa menyatakan, hal ini juga bagian dari strategi dalam menarik pemilih saat Pemilihan Gubernur 2018 lalu. Sementara survey mengenai masyarakat menyarankan orang lain ikut memilih setelah melihat jargon politik agama dan budaya sebagai media Komunikasi Politik di Pemilihan Gubernur 2018, sepertinya tidak sepedan dengan jumlah masyarakat dalam melakukan pemilihan langsung. Seperti hasil survey dibawah ini yakni hanya 55,7 persen 
yang menyarankan ke orang lain untuk memilih Koster-Ace saat menggunakan jargon agama budaya tersebut dan 44,3 persen tidak menyarankannya.

\section{Model Komunikasi Politik dengan Menggunakan Agaman dan Budaya dalam Pilgub Bali 2018}

Komunikasi Politik para calon dalam Pemilihan Gubernur Bali tahun 2018, para calon menggunakan media jargon agama budaya dalam kampanye politiknya untuk menggaet pemilih. Jargon agama budaya tersebut ternyata dilapangan ditemukan persepsi output postif dan output negatifnya. Pada output negatifnya ada kekhawatiran dari lembaga agama terhadap penggunaan jargon agama budaya tersebut sehingga lembaga agama kususnya dari PHDI melarang jika ada simbol agama dipakai sebagai politik praktis.

Namun saluran output negatif ini bisa dikendalikan dengan penggunaan jargon agama budaya dengan mengangkat sisi kearifan lokalnya, bukan dari sisi yang menimbulkan konflik SARA. Salah satunya yang dilakukan oleh Pasangan Calon Koster-Ace, yeng lebih mengedepankan konsep kearifan budaya Bali dalam memperbaiki alam Bali dengan jargon Nangun Sat Kertih Loka Bali.

Sedangkan output postif dalam jargon agama budaya tersebut dikembangkan oleh para calon untuk meyakinkan pemilih yakni dengan mengupas jargon agama budaya tersebut masuk pada visi dan misi calon dalam kampanye. Sehingga, jargon agama budaya ini tidak sekedar media komunikasi politik semata tapi juga sebagai media dalam pencapain program kerja yang harus dilaksankan ketika mereka terpilih. Tidak sampai disitu pengembangn juga dilakukan dari segi penampilan (dalam berbusana). Sebagai aktor politik, penampilan juga mempengaruhi dalam melegitimasi seorang calon terkesan baik di mata publik sehingga menjadi bagian modal atau selera budaya dalam ranah politik.
Pierre Bourdieu (1984) dalam karyanya Distinction: A Social Critique of the Judgment of Taste, yang disadur dalam bukunya Sufyanto $(2015 ; 15)$ "Selebritisasi Politik" menjelaskan praktek seorang dalam dunia sosial diantara habitus, modal, dan ranah (field), sebagaimana dapat digambarkan dengan rumusan (habitus $\mathrm{x}$ modal) + ranah $=$ praktik . Bourdieu berpendapat selera digunakan untuk melegitimasi perbedaan-perbedaan sosial sehingga ke kelas yang dominan maupun kelas yang didominasi dapat dilihat dari seleranya. Misalnya kehalusan bahasa, tata bahasa pengucapan, busana dan gaya merupakan modal budaya yang dijadikan faktor mobilitas sosial. Ini menjadi atribut aktor politik dan dapat didalami secara mendalam dalam jargon agama dan budaya sebagai modal komunikasi politik dalam Pilgub Bali.

\section{SIMPULAN}

Berdasarkan hasil penelitian, analisi data dan pembahasan tentang Jargon Politik Agama dan Budaya sebagai Media Komunikasi Politik dalam Pemilihan Gubernur Bali dapat disimpulkan sebagai berikut;

1. Jargon politik agama budaya memang menjadi media komunikasi politik para pasangan calon dalam Pemilihan Gubenrnur Bali 2018. Hal ini dapat terlihat dari sejumlah material dalam mekukan komunikasi politik untuk mengkampanyekan pasangan calon dalam Pemilihan Gubernur 2018 yang dalam penelitian ini adalah pasangan calon I Wayan Koster-Tjokorda Oka Artha Ardana Sukawati. Unsur-unsur penggunaan jargon komunikasi politik tersebut terlihat dalam penggunaan iklan saat kampanye, busana yang dikenakan yakni adat Bali tersebut menggunakan konsep kerifan lokal yakni Nangun Sat Kerthi Loka Bali. Selain itu, dalam analisis Teori Dramaturgi Erving Goffman, jargon politik agama budaya ini sebagai salah satu bagian dari panggung sandiwara politik dalam panggung depannya digunakan sebagai iklan politik dangan adanya sejumlah manipulasi 
dalam pembuatan iklan tersebut. Simpulan ini berdasarkan hasil temuan dilapangan serta wawancara mendalam narasumber kunci dalam pembuatan iklan jargon tersebut.

2. Jargon politik agama budaya ini menjadi daya tarik tersendiri di masyarakat atau pemilih di Bali. Hal ini berdasarkan hasil servei yang dilakukan peneliti terhadap respon pemilih dalam Pemilihan Gubernur tahun 2018 lalu dengan respon 87,6 persen mengaku tertarik untuk memilih dalam Pilgub Bali karena salah satunya adanya jargon agama budaya. Selain itu publik juga merespon terhadap jargon politik agama budaya tersebut dengan ingin tahun seperti apa saja jargon politik agama budaya yang digunakan. Bahkan dari survei yang dilakukan ke 100 responden di Bali secara acak, peneliti menemukan sebanyak 78, 4 persen responden ingin mencari tahu penggunaan jargon agama budaya sebagai media komunikasi politik dalam Pilgub Bali. Bahkan dari 100 renponden ada sebanyak 55,7 persen ikut menyarankan untuk memilih setelah mencari tahu apa saja jargon politik agama budaya yang digunakan.

3. Komunikasi politik yang menggunakan media jargon agama budaya dalam Pemilihan Gubernur ini bisa menimbulkan dua sisi pandangan dalam penggunaanya. Hal ini bisa menimbulkan hasil negatif dan hasil postif bagi pemilihnya. Tergantung, kemana arah penggunaan jargon agama budaya tersebut, apakah untuk media dalam dalam kampanye hitam untuk menimbulkan SARA atau lebih mengupas jargon agama budaya tersebut kedalam hal nilai-nilai postif kearifan lokal untuk membangun persatuan dan perbaikan alam Bali kedepannya. Selain itu, model komunikasi politik berbasis kearifan lokal, budaya, agama sesuai dengan karaksteristik kebudayaan Bali. Hal ini terlihat kosep yang digunakan pasangan calon Koster-Ace dalam jargon Nangun Sat kertih Loka Bali.

\section{DAFTAR PUSTAKA}

Aly, B.,2010, Komunikasi Pembangunan dengan Aksentuasi Komunikasi Politik. Jurnal Komunikasi Pembangunan. Volume 08 Nomor 2.

Akhirul, Aminulloh,2010, Komunikasi Politik Dakwah Partai Keadilan Sejahtera ,Jurnal Ilmu Komunikasi, Universitas Pembangunan Nasional Veteran Yogyakarta.

Cangara,Hafied,2016, Komunikasi Politik :Konsep, Teori dan Strategi, Rajagrafindo Persada, Jakarta.

Chris Barker,2014, Kamus Kajian Budaya,Kanisius,Yogyakarta.

Erving Goffman, 1974, The Presentation of Self ini Everyday Live, The Pinguin Press, London.

Effendi, Onong Uchjana,2017, Ilmu Komunikasi Teori dan Praktek, Remaja Rosdakarya, Bandung.

Kaelan, M.S.,2010,Metode Penelitian Kualitatif Interdisipiner-Metode Penelitian Ilmu Agama Inter Koneksi Inter Disipliner dengan Ilmu Lain, Paradigma,Yogyakarta.

Kaelan, M.S., 2012,Metode Penelitian Kualitatif Interdisipliner Bidang Sosial, Budaya, Filsafat, Agama dan Humaniora,Paradigma,Yogyakarta.

Kunandar, Alip Yog, 2017, Memahami Propaganda (Metode, Praktik dan Analisis), Kanisius, Yogyakarta.

Moleong, 2017, Metodelogi Penelitian Kualitatif, Remaja Rosdakarya, Badung.

Mkikmat, 2010, Desertasi Komunikasi Politik Calon Kepala Daerah Pada Pemilihan Langsung, Unversitas Islam Negeri Sunan Gunung Djati Bandung.

Norman K. Denzin \& Yvonna S. Lincoln (2009), Handbook of Qualitative Research (Edisi 
Bahasa Indonesia), Pustaka Pelajar, Yogyakarta.

Riris,Loisa \&Yugih Setsyanto,2012, makalah Mencari Bentuk Kampanye Politik Khas Indonesia: Pencitraan Berbasis Dimensi Budaya, Fakultas Ilmu Komunikasi Universitas Tarumanegara.

Sarwono,Sarlito W., 2018, Pengantar Psikologi Umum,Rajawali Pers, Depok.

Susanto, Eko Harry, 2013, Dinamika Komunikasi Politik Dalam Pemilihan Pemilu, Jurnal Kajian Komunikasi volume 1, nomor 2, Fakultas Ilmu Komunikasi, Universitas Tarumanegara Jakarta.

Sufyanto ,2015,Selebritisasi Politik Kajian Dramaturgi, Habitus dan Tindakan Komunikatif Aktor Politik,Nusa Media, Bandung.

Suharto,2013, Urgensi Komunikasi Politik Dakwah, Jurnal Dakwah Tabligh, Universitas Islam Negeri Alauddin Makasar.

Walgito,Bimo,2010,Pengantar Psikologi Umum, ANDI, Yogyakarta.

W.J.S Poerwadaminta ,1991, Kamus Umum Bahasa Indonesia cet. XII, Balai Pustaka, Jakarta.

Wiana I Ketut ,2015, Berpolitik menurut Hindu, Paramita, Surabaya. 